\title{
Tilakoon kasvu pakottaa hakemaan vaihtoehtoja omalle työlle
}

Perttu Pyykkönen

Pellervon taloudellinen tutkimuslaitos, Eerikinkatu 28,00180 HELSINKI, perttu.pyykkonen@ptt.fi

Tiivistelmä: Maatalouden rakennekehityspaineet jatkuvat kovina. Samalla yksittäisten tilojen investoinnit ovat myös selvästi suurentuneet. Myös tuotantoteknologia kehittyy, mutta siitä huolimatta oma työpanos ei välttämättä riitä kasvavilla tiloilla. Se pakottaa maatalousyrittäjät miettimään vaihtoehtoisia tapoja organisoida tilan tuotanto ja työvoiman käyttö.

Tutkimuksessa selvitetään, millaisia toiminnallisia muutoksia maatiloilla tehdään rakennekehityksen myötä. Pääpaino on vieraan työvoiman ja ostopalveluiden käytön muutosten tarkastelussa. Tutkimusaineistona on laaja viljelijäkysely.

Itse tekemisen perinne suomalaisessa maataloudessa on hyvin vahva. Lähes neljännes tiloista tekee kaikki työt itse. Vieraan työvoiman palkkaus on suhteellisen vähäistä eikä yhteistyön ja ostopalveluiden käytölläkään säästetä omaa työtä pääsääntöisesti kuin muutamia päiviä. Itse tekeminen on yleisintä niillä tiloilla, joilla yksi tai kaksi henkilöä työllistyy päätoimisesti. Jos tila tarjoaa viljelijälle tai puolisolle vain osa-aikaisesti työtä, vierailla teetetyn työn osuus on suurempi.

Keskimääräinen oman työn osuus on työstä riippuen 50-90 \%. Yleisintä rahtityön teettäminen on kuivauksessa, puinnissa ja lannanlevityksessä. Itse tekeminen on yleisintä puolestaan muokkaus- ja kylvötöissä. Tilanne on kuitenkin muuttumassa, sillä viiden vuoden päässä kyselyajankohdasta itse tehdyn työn osuuden arvioitiin olevan 15-20 \% vähäisempi. Sekä yhteistyön että ostopalveluiden käytön arvioidaan lisääntyvän etenkin isoilla tiloilla. Pienet tilat sen sijaan jatkavat liki entiseen malliin. Isoilla tiloilla ostopalvelujen käytön tärkeimmät syyt ovat oman ajan puute ja työhuippujen tasaaminen. Pienillä tiloilla taasen ei kannata hankkia omia koneita.

Yhteistyöllä saavutetaan kustannussäästöjä mutta siihen, mikä on varsinkin suurilla kotieläintiloilla rajoittavin tekijä eli oma työ, sillä ei voida paljoakaan vaikuttaa. Sen ongelman ratkaisee vasta urakoitsijoiden käyttö ja töiden ulkoistaminen. Jo nyt myös vierasta työvoimaa palkattaisiin enemmän, jos siihen olisi taloudellisia mahdollisuuksia. Tosin myös ammattitaitovaatimukset ovat koventuneet eikä maatalous tunnu houkuttelevan nuoria alalle alhaisen palkkatason takia. Tiloilla on valmiutta myös yhteistyöhön toisten tilojen kanssa vieraan työvoiman palkkaamisessa.

Rakennekehityksen myötä viljelijöiden täytyy jatkossa tehdä entistä tarkemmin valintoja siitä, mitä kannattaa tehdä itse, mitä kannattaa teettää vieraalla, ja mitä toimintoja kannattaa ulkoistaa. Yksi iso tulevaisuuden haaste on, miten työssä jaksaminen hoidetaan tilakoon kasvaessa etenkin suurilla kotieläintiloilla. Ulkoistaminen ja varsinkin yhteistyön lisääminen voivat olla vain osittaisratkaisuja. Sen takia mahdollisuudet vieraan työvoiman palkkaamiseen vaikkapa mahdollisten tukitoimenpiteiden avulla on kartoittava tarkkaan. Tämä olisi tärkeää etenkin nuorten tuotantoonsa investoineiden viljelijöiden tiloilla, joilla ei välttämättä muutoin ole mahdollisuuksia palkata työvoimaa.

Asiasanat: Rakennekehitys, yhteistyö, vieras työvoima. 


\section{Johdanto}

Maatalouden rakennekehityspaineet jatkuvat kovina. Samalla yksittäisten tilojen investoinnit ovat myös selvästi suurentuneet. Myös tuotantoteknologia kehittyy, mutta siitä huolimatta oma työpanos ei välttämättä riitä kasvavilla tiloilla. Se pakottaa maatalousyrittäjät miettimään vaihtoehtoisia tapoja organisoida tilan tuotanto ja työvoiman käyttö.

Suurin osa maatalousyritysten prosesseista hoidetaan nyt ja vastaisuudessakin yrityksen omin resurssein. Vieraan työvoiman käyttö kuitenkin lisääntyy yrityskoon kasvaessa, jolloin maatalousyrittäjän on kyettävä päätöksissään analysoimaan vieraasta työvoimasta aiheutuvia kustannuksia ja sillä saavutettavia hyötyjä, jotka eivät ole aina selkein taloudellisin indikaattorein mitattavissa.

Toisaalta huomattava osa yrityksen toiminnallisista prosesseista voidaan antaa ulkopuolisen palveluntuottajan tehtäväksi. Ostopalveluiden kysynnän voidaan olettaa riippuvan maatalousyrityksen koosta. Suurilla tiloilla työvoiman riittämättömyys voi johtaa toimintojen ulkoistamiseen. Pienillä tiloilla puolestaan kaluston rajallinen käyttöaika ei mahdollista omia investointeja jokaiseen tuotantoprosessiin. Pienillä osa-aikatiloilla ei myöskään oma aika usein riitä töiden tekemiseen, jos ollaan tilan ulkopuolella kokopäiväisessä työssä. Jos vakituisen työvoiman tarve mitoitetaan ympärivuotisen työn kysynnän mukaisesti, ajoittaisten työhuippujen tasaamiseen on usein taloudellisesti järkevää käyttää ostopalveluita. Näiden palvelujen rationaalisella käytöllä on mahdollista parantaa yrityksen taloudellista kannattavuutta. Toimintojen organisointitavalla on myös vaikutuksia tilojen kustannusrakenteeseen ja velkaantumisen tasoon.

Yrittäjien välisellä yhteistyöllä on pitkät perinteet. Yhteistyön avulla voidaan tehostaa maatalouden konekannan käyttöä ja samalla pienentää kalustokustannuksia. Myös markkinoinnissa ja hankinnoissa on mahdollista toimia yhdessä. Yhteistyön muotojen ja organisointitapojen voidaan olettaa muuttuvan ajan kuluessa. Esimerkiksi koneyhteistyön kohdalla voidaan olettaa, että suuntaus on yhteiskäytöstä entistä suurempaan työvaiheittaiseen erikoistumiseen. Rajanveto yhteistyön ja urakoinnin välillä on kuitenkin hämärtymässä.

Tutkimuksen tavoitteena oli selvittää, millaisia toiminnallisia muutoksia maatiloilla on toteutettu ja toteutuu jatkossa maatalouden rakennekehityksen osatekijänä. Päähuomio kiinnitettiin työn ja eri toimintojen organisointiin. Keskeistä oli selvittää, kuka tekee, miten tehdään, ja miksi tilalla toimitaan siten, kuin toimitaan. Tässä tutkimuksessa selvitetään maatalouden vieraan työvoiman käyttöä, ostopalveluiden ja yrittäjien yhteistyön tulevaisuuden näkymiä sekä niiden taloudellista merkitystä.

\section{Tutkimusaineisto}

Tutkimusaineisto muodostuu laajasta viljelijäkyselystä, joka toteutettiin syyskesällä 2005. Kyselyn toteutti Suomen Gallup Elintarviketieto. Aineisto kerättiin postikyselyllä ja analysoitiin erilaisten luokittelujen ja ristiintaulukointien avulla.

Kyselyn avulla haettiin vastauksia kysymykseen, miten maatalousyrityksen tuotantoprosesseista työnkäyttö on organisoitu. Aikaulottuvuus tutkimukseen saatiin siten, että tiloilta kysyttiin tilan nykyistä toimintatapaa (vuonna 2005) ja arvioita siitä, miten tilalla toimitaan seuraavan viiden vuoden päästä.

Tutkimuksen perusjoukon muodostivat yli viiden peltohehtaarin maatilat, joita oli kyselyhetkellä noin 60 000. Kyselyn otoksen muodostivat 930 viljelijää, joiden vastaukset painotettuna alueen, tuotantosuunnan ja tilakoon mukaan vastaavat perusjoukkoa. Tilojen jakautuminen em. taustamuuttujien mukaan on esitetty taulukossa 1. Aineiston tilat olivat otantaperusteesta johtuen tilakooltaan suurempia kuin Suomen maa tilat keskimäärin (42 ha vs. 
$33 \mathrm{ha})$.

Taulukko 1. Tutkimusaineiston jakautuminen tuotantosuunnittain, tilakokoluokittain ja EUtukialueittain.

\begin{tabular}{|lc|lc|lc|}
\hline Tuotantosuunta & $\%$ & Tilakoko & $\%$ & EU-tukialue & $\%$ \\
\hline Nautatalous & 34 & $01-14$ ha & 22 & A-alue & 14 \\
Sikatalous & 5 & $15-29$ ha & 28 & B-alue & 31 \\
Viljanviljely & 39 & $30-49$ ha & 25 & C1-alue & 23 \\
Erikoiskasvinviljely & 6 & $50-74$ ha & 13 & C2-alue & 25 \\
Muu tuotantosuunta & 15 & $>=75$ ha & 9 & C2P-C4-alue & 6 \\
Ei tietoa & 1 & Ei tietoa & 2 & & \\
\hline
\end{tabular}

\section{Tutkimustulokset}

Itse tekemisen perinne suomalaisessa maataloudessa on hyvin vahva. Lähes neljännes tiloista tekee kaikki työt itse. Keskimääräinen oman työn osuus on työstä riippuen 50-90 \%. Yleisintä rahtityön teettäminen on kuivauksessa, puinnissa ja lannanlevityksessä. Muokkaus- ja kylvötyöt sen sijaan tehdään yleisimmin itse. Tilanne on kuitenkin muuttumassa, sillä viiden vuoden päässä kyselyajankohdasta itse tehdyn työn osuuden arvioitiin olevan 15-20 \% vähäisempi (kuvio 1). 


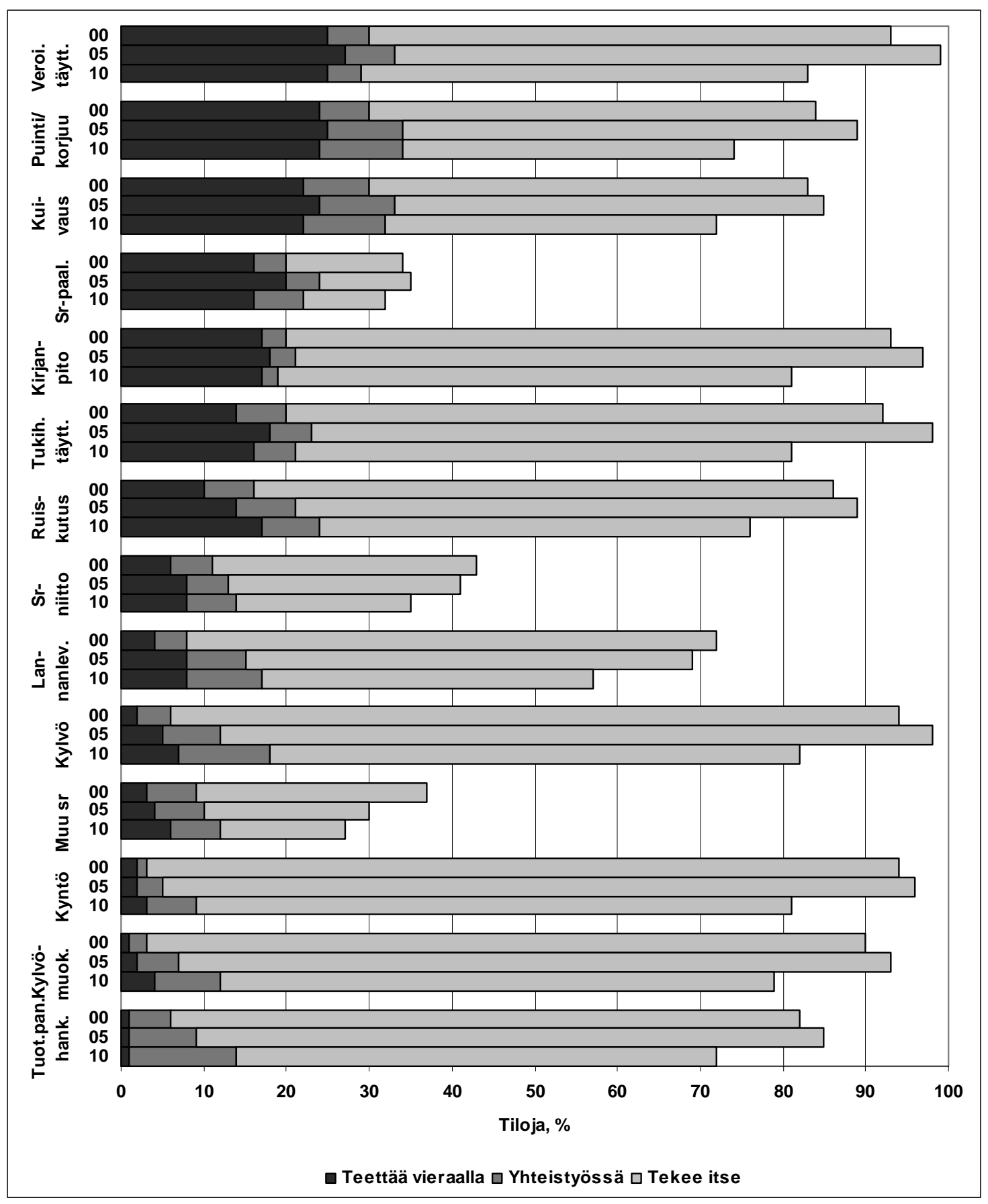

Kuvio 1. Itse tehdyn, yhteistyössä tehdyn ja urakoitsijalla teetettyjen töiden osuudet 2000-2010.

Vieraan työvoiman palkkaus on suhteellisen vähäistä eikä yhteistyön ja ostopalveluiden käytölläkään säästetä omaa työtä pääsääntöisesti kuin muutamia päiviä. Sekä yhteistyön että ostopalveluiden käytön arvioidaan lisääntyvän etenkin isoilla tiloilla. Pienet tilat sen sijaan jatkavat liki entiseen malliin (Kuvio 2). Isoilla tiloilla ostopalvelujen käytön tärkeimmät syyt ovat oman ajan puute ja työhuippujen tasaaminen. Pienillä tiloilla taas ei kannata hankkia omia koneita. Pienillä tiloilla konepääoman säästön arvioitiin olevan yli $20 \%$ verrattuna siihen, että työt tehtäisiin itse. Isoilla tiloilla säästö jäi pienemmäksi, mutta niilläkin se oli noin 15 \%. Koko luokasta riippuen vuonna 2010 säästöjen arvioitiin olevan 20-30 \%. 


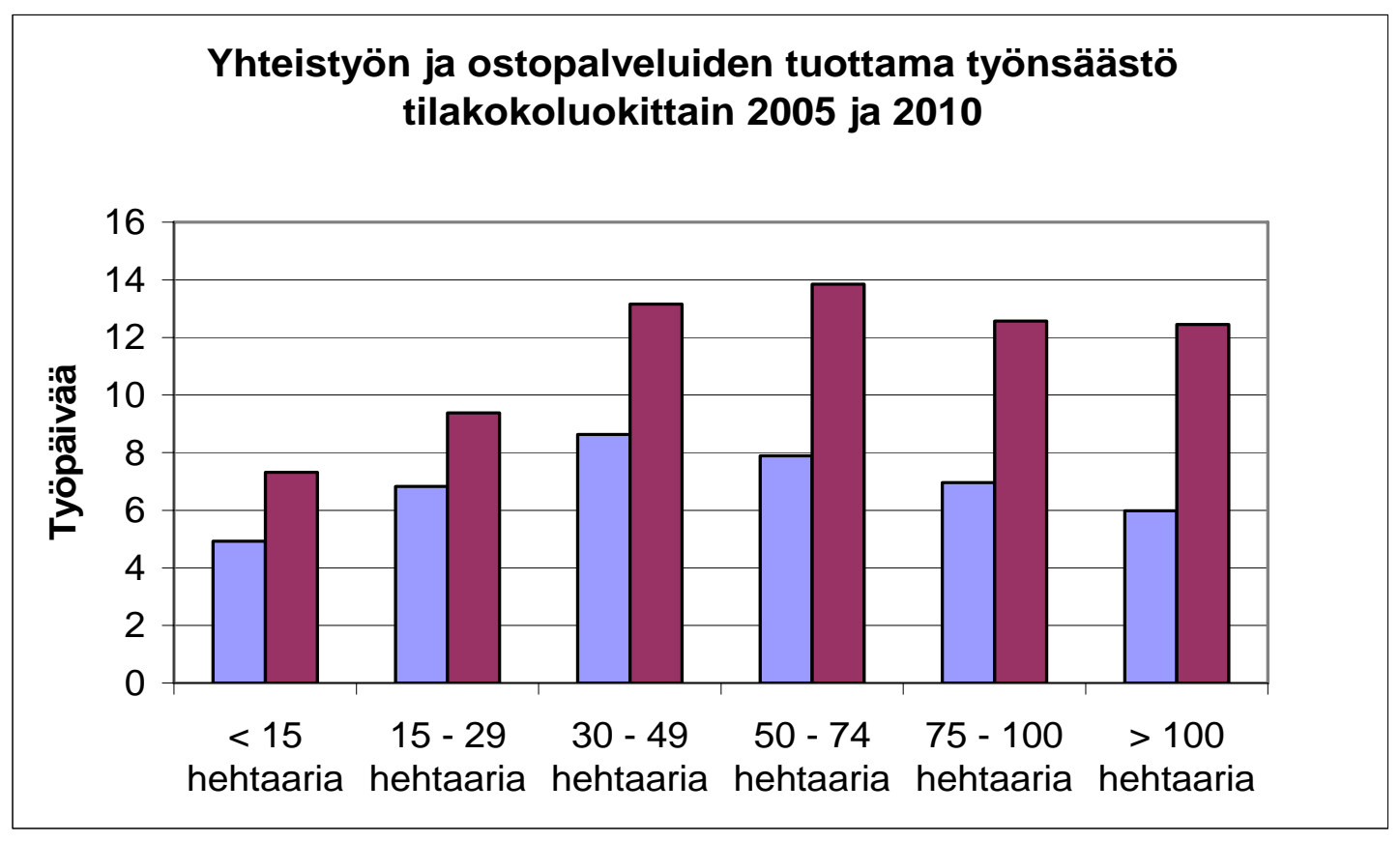

Kuvio 2. Yhteistyöllä ja ostopalveluiden käytöllä saavutettu työnsäästö eri tilakokoluokissa.

Itse tekeminen on yleisintä niillä tiloilla, joilla yksi tai kaksi henkilöä työllistyy päätoimisesti. Jos tila tarjoaa viljelijälle tai puolisolle vain osa-aikaisesti työtä, vierailla teetetyn työn osuus on suurempi. Tämä näkyy selvästi kuviosta 3, kun tarkastellaan 9-12 ja 21-24 kuukautta työllistävien tilojen työnkäytön jakaumaa. Näillä yksi tai kaksi henkilöä kokopäivätoimisesti työllistävillä tiloilla viljelijäperheen itse tekemän työn osuus on kaikkein suurin sekä absoluuttisesti että suhteellisesti.

Jos esimerkiksi toisella puolisoista on tilan ulkopuolinen työpaikka, niin siitä pidetään kiinni ja niitä töitä, joihin yhden hengen työpanos ei riitä, teetetään muilla. Jos tila kuitenkin työllistää kaksi henkilöä täysiaikaisesti, niin silloin ulkopuolisesta työpaikasta voidaan herkemmin luopua ja siirtyä kokonaan tilalle. Tämä viittaa viljelijöiden haluun olla päätoimisia, mutta myös siihen, että tilan töiden mukaan joustavia ulkopuolisia työpaikkoja on hankala löytää. 


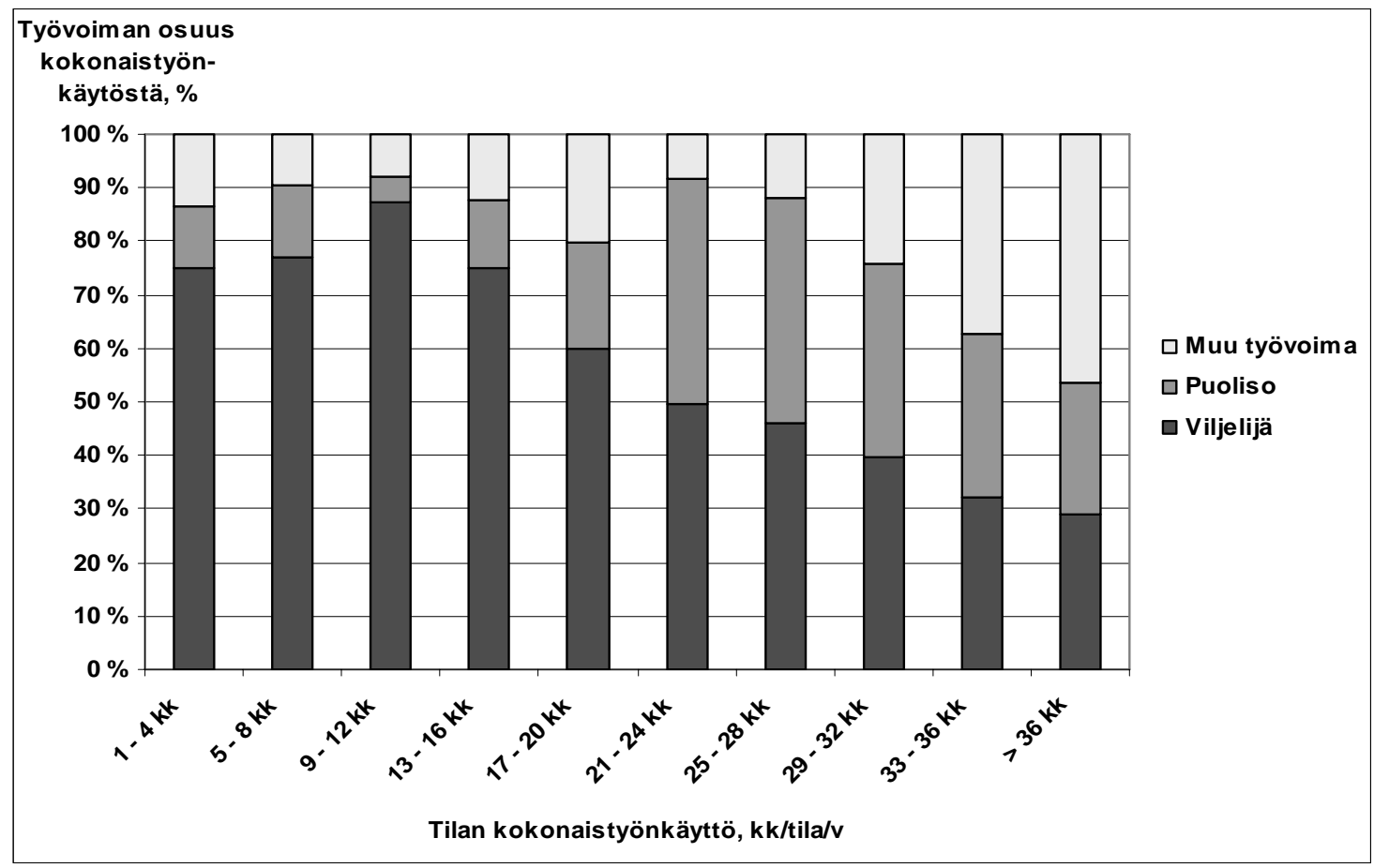

Kuvio 3. Tilojen kokonaistyömäärän jakautuminen viljelijän, puolison ja muun työvoiman kesken kokonaistyönkäytöltään erisuuruisilla tiloilla vuonna 2005.

Yhteistyö säästää pääomakustannuksia mutta siihen, mikä on varsinkin suurilla kotieläintiloilla rajoittavin tekijä eli oma työ, sillä voidaan vaikuttaa rajoitetummin. Siihen ongelmaan parempi ratkaisu on urakoitsijoiden käyttö ja töiden ulkoistaminen. Jo nyt myös vierasta työvoimaa palkattaisiin enemmän, jos siihen olisi taloudellisia mahdollisuuksia. Tosin myös ammattitaitovaatimukset ovat koventuneet eikä maatalous tunnu houkuttelevan nuoria alalle alhaisen palkkatason takia. Tiloilla on valmiutta myös yhteistyöhön toisten tilojen kanssa vieraan työvoiman palkkaamisessa (kuviot 4 ja 5). 
Maatalouden huono kannattavuus estää vieraan työvoiman palkkaamisen

Palkkataso on liian alhainen, jotta se houkuttelisi nuoria alalle

\section{Teknologinen kehitys on lisännyt} am m attitaitovaatim.

On paljon töitä, joita pystyy tekemään vähälläkin koulutuksella

Jos vieraan työvoiman palkkaam ista tuettaisiin, käyttäisin enem män vierasta työvoim aa

Työhuippujen aikaan on vaikea saada palkkaväkeä

Maataloustyö ei kiinnosta suomalaisnuoria

Käytän mieluum min rahtipalveluita kuin palkkaan vierasta työvoim aa

Tarvitsis in palkattua työvoimaa jakamaan omaa työtaakkaani

Palkkaisin mielelläni yhteisen työntekijän ympärivuotisesti muutaman tilan kanssa

Palkatut työntekijät eivät jousta työhuippujen aikaan riittävästi

Käyttäisin enem män vierasta työvoimaa, jos sitä saisi helpom $\mathrm{min}$

Ammattikoulutus on liian viljelijäsuuntautunutta, eikä huomioi tarpeeksi tilojen työvoiman tarvetta

Ympärivuotiseen työsuhteeseen on helppo löytää palkkaväkeä
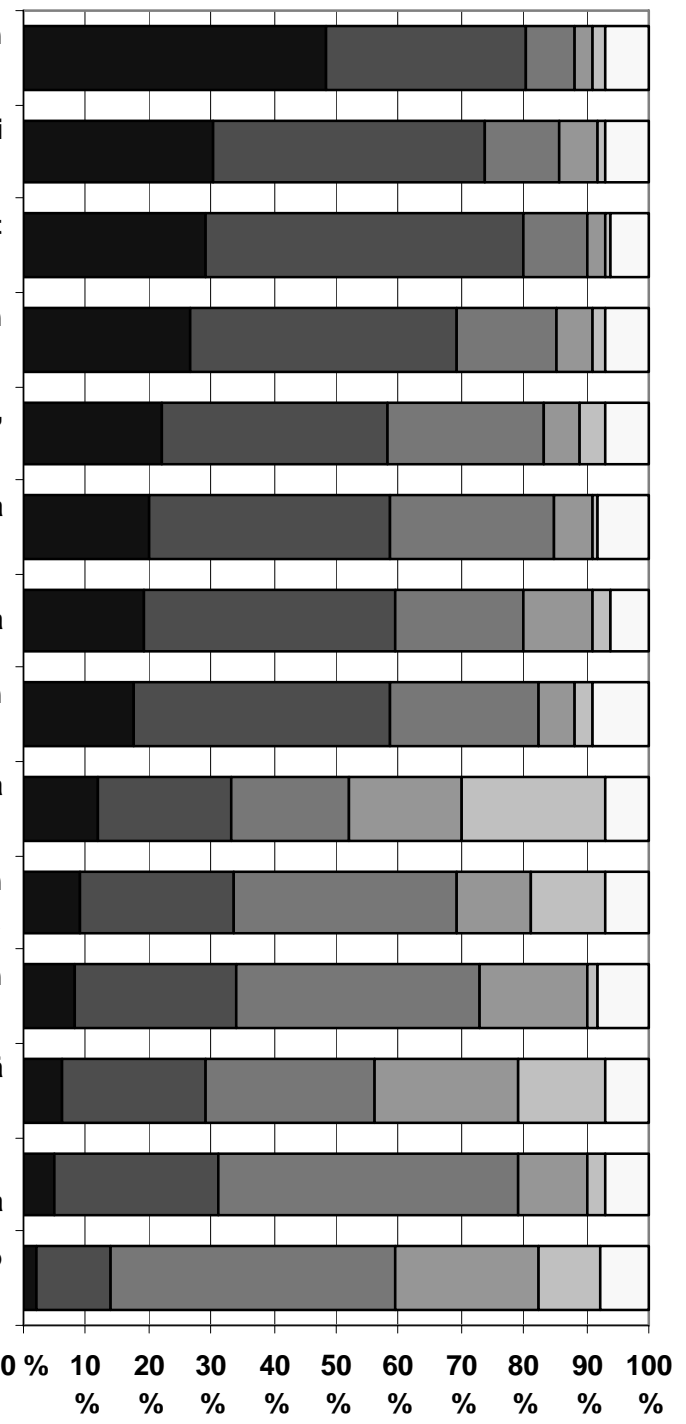

Tiloja, \%

— täysin samaa mieltä $\square$ pääosin samaa mieltä $\square$ ei samaa eikä eri mieltä $\square$ pääosin eri mieltä $\square$ täysin eri mieltä $\square$ ei vast.

Kuvio 4. Vastaajien mielipiteet vieraan työvoiman palkkaamisesta. 


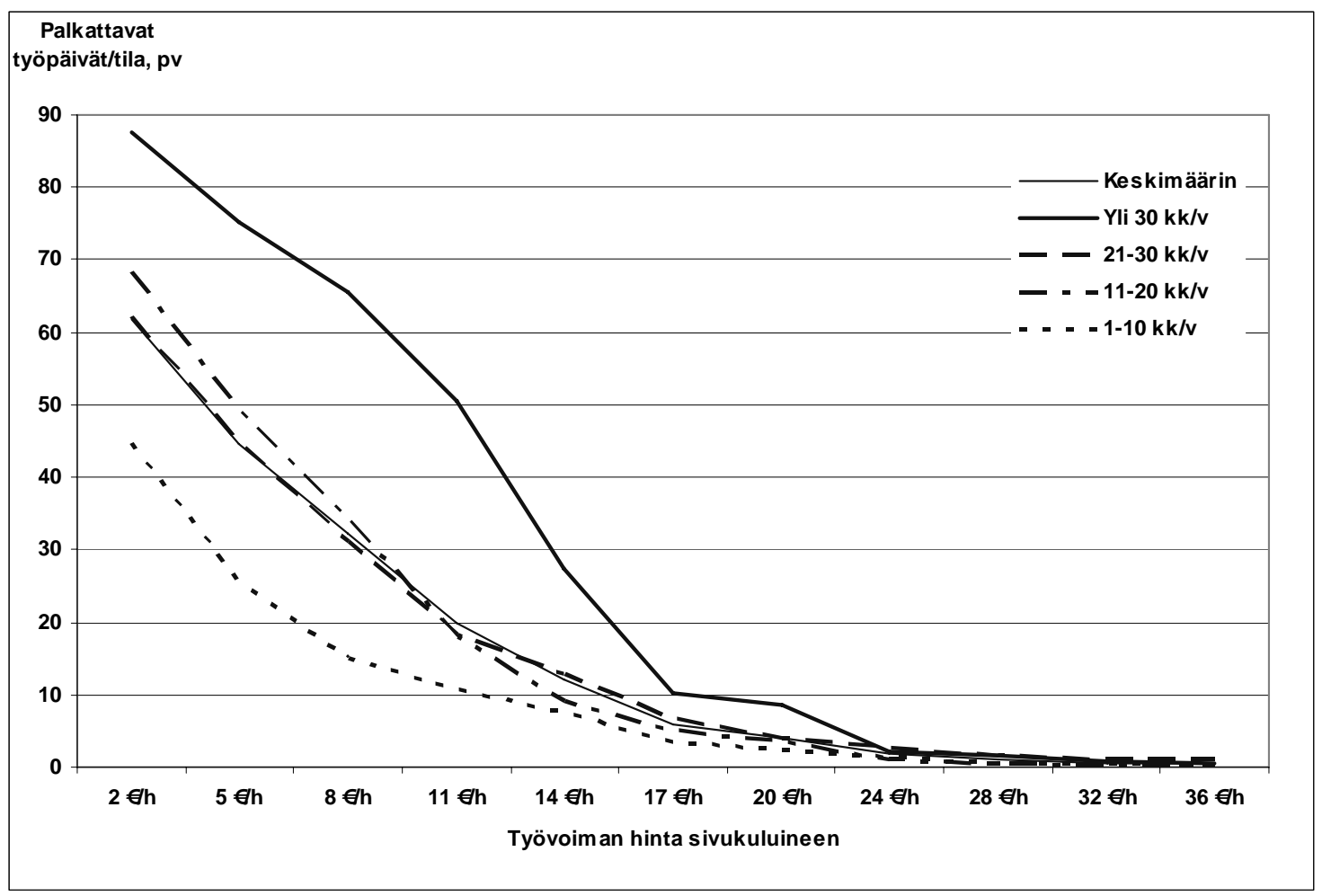

Kuvio 5. Työvoiman kysyntäkäyrä työnkäytöltään erisuuruisilla tiloilla.

\section{Johtopäätökset}

Rakennekehityksen myötä viljelijöiden täytyy jatkossa tehdä entistä tarkemmin valintoja siitä, mitä kannattaa tehdä itse, mitä kannattaa teettää vieraalla, ja mitä toimintoja kannattaa ulkoistaa. Yksi iso tulevaisuuden haaste on, miten työssä jaksaminen hoidetaan tilakoon kasvaessa etenkin suurilla kotieläintiloilla. Ulkoistaminen ja varsinkin yhteistyön lisääminen voivat olla vain osittaisratkaisuja. Sen takia mahdollisuudet vieraan työvoiman palkkaamiseen vaikkapa mahdollisten tukitoimenpiteiden avulla on kartoittava tarkkaan. Tämä olisi tärkeää etenkin nuorten tuotantoonsa investoineiden viljelijöiden tiloilla, joilla ei välttämättä muutoin ole mahdollisuuksia palkata työvoimaa. 